\title{
Bioorganometallic Technetium and Rhenium Chemistry: Fundamentals for Applications
}

\author{
Roger Alberto*, Henrik Braband, and Qaisar Nadeem
}

\begin{abstract}
Due to its long half-life of $2.111 \times 10^{5} \mathrm{y}$, technetium, i.e. ${ }^{99} \mathrm{Tc}$, offers the excellent opportunity of combining fundamental and 'classical' organometallic or coordination chemistry with all methodologies of radiochemistry. Technetium chemistry is inspired by the applications of its short-lived metastable isomer ${ }^{99 m} \mathrm{Tc}$ in molecular imaging and radiopharmacy. We present in this article examples about these contexts and the impact of purely basic oriented research on practical applications. This review shows how the chemistry of this element in the middle of the periodic system inspires the chemistry of neighboring elements such as rhenium. Reasons are given for the frequent observation that the chemistries of ${ }^{99} \mathrm{Tc}$ and ${ }^{99 \mathrm{~m}} \mathrm{Tc}$ are often not identical, i.e. compounds accessible for ${ }^{99 \mathrm{~m} T c}$, under certain conditions, are not accessible for ${ }^{99} \mathrm{Tc}$. The article emphasizes the importance of macroscopic technetium chemistry not only for research but also for advanced education in the general fields of radiochemistry.
\end{abstract}

Keywords: Bioorganometallics · Molecular Imaging · Radiopharmacy · Rhenium · Technetium

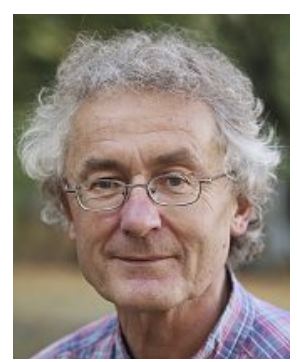

Roger Alberto obtained his $\mathrm{PhD}$ from the ETH Zurich. He was an Alexander von Humboldt fellow in the group of W.A. Herrmann at the TU Munich and at the Los Alamos National Laboratory with A Sattelberger. He then joined the Paul Scherrer Institute with A. Schubiger in 1991. In 2000, he joined the University of Zurich and was elected full professor in 2006 . He headed the Institute of Inorganic Chemistry from 2006-2013 and the Department of Chemistry from 20122016. Since 2013, he leads 'LightChEC', a University Research Priority Program. Among others, he was awarded an Alexander von Humboldt research award and the Heilbronner-Hückel lectureship of the GDCh. His research interests are synthetic radiochemistry, molecular imaging, bioorganometallic chemistry and artificial photosynthesis.

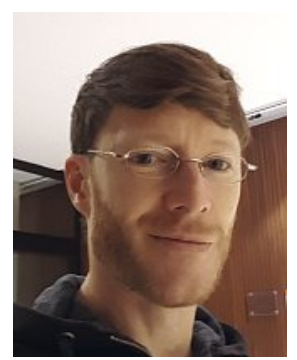

Henrik Braband obtained his $\mathrm{PhD}$ from the Free University of Berlin in 2006. In the same year, he joined the research group of Roger Alberto at the University of Zurich (UZH) as a postdoctoral fellow. From 2009-2013 he was an Ambizione fellow of the Swiss National Science Foundation. Since 2013, Henrik Braband is group leader in the Alberto research group. He is the laboratory manager of the radiochemistry facility and head of radiation safety of the Department of Chemistry of UZH. His research interests are synthetic radiochemistry, molecular imaging, bioorganometallic chemistry and nanomaterials for (nuclear) medical applications.

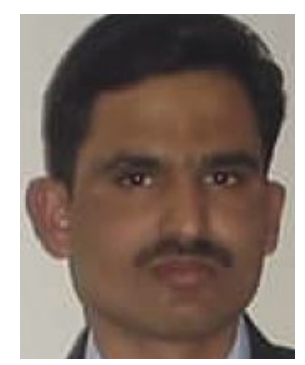

Qaisar Nadeem got his $\mathrm{PhD}$ from the University of the Punjab Lahore, Pakistan. He received the higher education commission (HEC, Pakistan) fellowship during his $\mathrm{PhD}$ and worked in the Alberto group, Department of Chemistry University of Zurich, on the synthesis of ${ }^{99 \mathrm{~m}} \mathrm{Tc}$ complexes of cyclopentadienyl-derivatized, bioactive peptides. Dr. Qaisar Nadeem became Assistant Professor of Chemistry for three years at the Islamia University of Bahawalpur before moving back to the Alberto research group, as a postdoctoral fellow since 2018, he is working on the aqueous synthesis of ${ }^{99 \mathrm{~m}} \mathrm{Tc}$ bis-arene complexes.

\section{Introduction}

\subsection{Historical Development of Technetium Chemistry}

Technetium is a man-made element, discovered and characterized by C. Perrier and the Nobel laureate E. Segrè in 1937. ${ }^{[1]}$ Since it was only available in trace amounts from cyclotron-irradiated molybdenum foils, some time passed before the exploration of its chemistry on the macroscopic level could start. The first reports on technetium chemistry on a weighable scale appeared in the early fifties, when ${ }^{99} \mathrm{Tc}$ became available from the workup of spent nuclear fuels. ${ }^{[2]}$ Since about $6 \%$ of all fission products is ${ }^{99} \mathrm{Tc}$, chemistry on the gram scale was no problem at that time, especially since the half-life of $2.111 \times 10^{5} \mathrm{y}$ is rather long, making its specific activity reasonably low. In addition, ${ }^{99} \mathrm{Tc}$ is a weak $\beta^{-}$-emitter, the radiation of which is essentially absorbed by the walls of normal glassware keeping exposition to ionizing radiation at a reasonable level when following standard radiochemical radiation protection measures as requested by the authorities. For a long time, technetium was considered just an 'exotic' artificial element and not too much attention was paid to it. This changed when Brookhaven National Laboratory discovered the ${ }^{99} \mathrm{Mo} /{ }^{99 \mathrm{~m}} \mathrm{Tc}$ generator and the very favorable properties of the metastable nuclide ${ }^{99 \mathrm{~m}} \mathrm{Tc}$ for nuclear medicine purposes. ${ }^{[3]}$ Since ${ }^{99 \mathrm{~m}} \mathrm{Tc}$ has a half-life of only $6 \mathrm{~h}$, macroscopic chemistry is impossible. To characterize the authenticities of ${ }^{99 \mathrm{~m}} \mathrm{Tc}$ complexes, it is essential to prepare the long-lived 
${ }^{99} \mathrm{Tc}$ analogues and to compare, e.g. their retention times in ITLC or HPLC. Recognizing the high importance and convenience of ${ }^{99 \mathrm{~m}} \mathrm{Tc}$ for nuclear medicine initiated a stormy development in technetium chemistry with ${ }^{99} \mathrm{Tc}$. The main purpose was to fully characterize compounds of ${ }^{99 \mathrm{~m}} \mathrm{Tc}$ by studying ${ }^{99} \mathrm{Tc}$ but even more to discover and develop new complexes for functional imaging. Fundamental coordination compounds and organometallic complexes were synthesized and characterized in the seventies, the eighties and the nineties. Numerous groups were active worldwide in technetium chemistry and reviews appeared regularly about progresses and advances. Technetium even had its own dedicated conference. ${ }^{[4]}$

Despite this thrust for new technetium compounds, many fundamental fields remained essentially untouched, in particular those with no immediate perspective of application in nuclear medicine. This concerned especially organometallic compounds but also fundamental structures such as the binary halides, which are core in the chemistry of the neighboring transition elements. Only recently, A. Sattelberger and coworkers filled one of these gaps with a systematic study about technetium halide preparations and structures. ${ }^{[5]}{ }^{99 \mathrm{~m}} \mathrm{Tc}$ is a nuclide for Single Photon Emission Computed Tomography (SPECT). Since the new century, Positron Emission Tomography (PET) set out to compete with or rather to complement SPECT. This led to a decreasing relevance of ${ }^{99} \mathrm{Tc}$ and ${ }^{99 \mathrm{~m}} \mathrm{Tc}$ chemistry. Together with ever-growing radiation safety considerations, fundamental technetium chemistry started to decline as well. Despite the fact that still around $80 \%$ of all nuclear medicine diagnoses are done with ${ }^{99 \mathrm{~m}} \mathrm{Tc},{ }^{66}$ essentially no new compounds entered the health care market since, among other reasons, basic studies with ${ }^{99} \mathrm{Tc}$ became fewer and fewer. This is somewhat surprising since, apart from application-driven research, fundamentals are equally important. Following trends as found in other fields, support for fundamental research is more and more difficult to acquire. Nowadays, only a handful of groups are still pursuing technetium chemistry with ${ }^{99} \mathrm{Tc}$, in pure fundamentals ${ }^{[7]}$ or fundamentals directed towards application as this author's group and a few others, ${ }^{[8]}$ in nuclear waste management, ${ }^{[9]}$ in the environmental sciences ${ }^{[10]}$ and many in labelling chemistry, but with ${ }^{99 m}$ Tc only. Fig. 1 shows a reduced excerpt with radioisotopes of technetium and the neighboring elements molybdenum and ruthenium. ${ }^{[11]}$ Since all mass numbers are occupied by stable isotopes of the latter two elements, no stable technetium exists. ${ }^{[12]}$

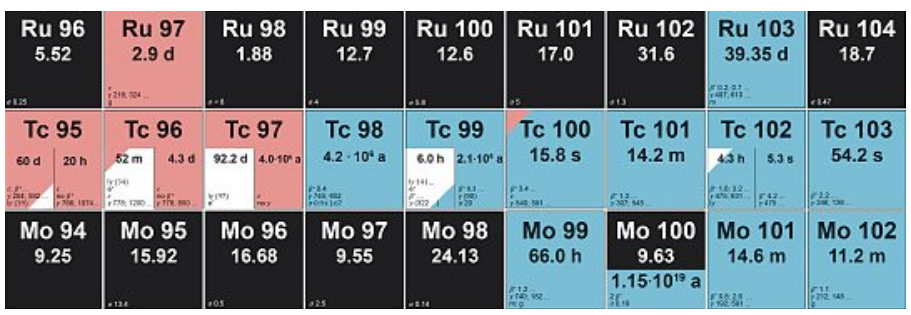

Fig. 1. Adapted excerpt from the Karlsruhe Nuclide Chart, showing the radionuclides of ruthenium, technetium and molybdenum. ${ }^{[1]]}$

\subsection{Opportunities in Technetium Chemistry}

In the periodic table, technetium lies towards the middle of the transition element series. This makes its chemistry very interesting, since it possesses properties of the early and the later delements. It represents a nice example for diagonal relationships within the periodic table. In its chemistry in the higher oxidation states, it is different from its heavier homologue rhenium but resembles this element very well in the lower valences. Since lowvalent organometallic chemistry became more and more important for the labelling of targeting biomolecules, many research groups are doing rhenium chemistry as a substitute for ${ }^{99} \mathrm{Tc}$ and as a surrogate for ${ }^{99 \mathrm{~m}} \mathrm{Tc}$. This so-called matched-pair situation is becoming more and more important since the pure imaging opportunities with ${ }^{99 \mathrm{~m}} \mathrm{Tc}$ are complemented by strongly increasing activities exploring the cyto- or phototoxic properties of rhenium organometallic compounds as pointed out by Gasser et al. ${ }^{[13]} \mathrm{In}$ the matched-pair concept, ${ }^{99 \mathrm{~m}} \mathrm{Tc}$ complexes would be used for imaging and its rhenium homologues for chemotherapy, thus opening a unique pathway for theranostics hardly encountered for any other set of elements. ${ }^{[13,14]}$ This concept requires, however, that the compounds have to be prepared with ${ }^{99 \mathrm{~m}} \mathrm{Tc}$ in water together with rhenium, which is not such an easy prerequisite as it might look at first glance (vide infra). Alternatively, matching ${ }^{99 \mathrm{~m}} \mathrm{Tc}$ chemistry with rhenium could also be a combination with ${ }^{188} \mathrm{Re}$ or ${ }^{186} \mathrm{Re}$, two radioisotopes with excellent radiotherapeutic properties but difficult to obtain in appropriate qualities and quantities. ${ }^{[15]}$

Labelling with ${ }^{99 \mathrm{~m}} \mathrm{Tc}$ is based on several strategies, each of them requiring broad skills and interdisciplinary vistas. Originally, the preparation of new radiopharmaceuticals for imaging purposes focused on the synthesis of new complexes, so-called 'de novo' radiopharmaceuticals. Cardiolite ${ }^{\circledR}$, an extremely successful myocardial imaging agent, is such an example (Fig. 2A). Cardiolite ${ }^{\circledR}$ is still in routine clinical application despite being more than thirty years old. ${ }^{[16]}$ De novo radiopharmaceuticals are hardly a topic nowadays since their development is costly and other diagnostic methods may well compete. A second generation of radiopharmaceuticals are targeting molecules such as peptides, proteins or small molecules which are tagged with a ${ }^{99 \mathrm{~m}} \mathrm{Tc}$ complex. Second-generation radiopharmaceuticals are still topological foci although, over the years, only a small number of such imaging agents were or are introduced into the market.[17] The labelling of targeting molecules demands skills in the design and synthesis of tailor-made ligands. These have to be conjugated to the biovectors without affecting their biological properties. Finally, the new conjugates have to be labelled with a ${ }^{99 \mathrm{~m}} \mathrm{Tc}$ core and be subjected to biological studies. These individual steps have to be combined, thus, involved research covers many subfields ranging from inorganic chemistry to radiochemistry and biological sciences. The interdisciplinary character makes it highly demanding, but also interesting since learning all the skills for the development of second generation radiopharmaceuticals is advantageous for academic progress. A good example for outlining this interdisciplinary nature is the recently presented prostate imaging agent MIP-1404 which is going to be commercialized soon (Fig. 2B). ${ }^{[18]}$
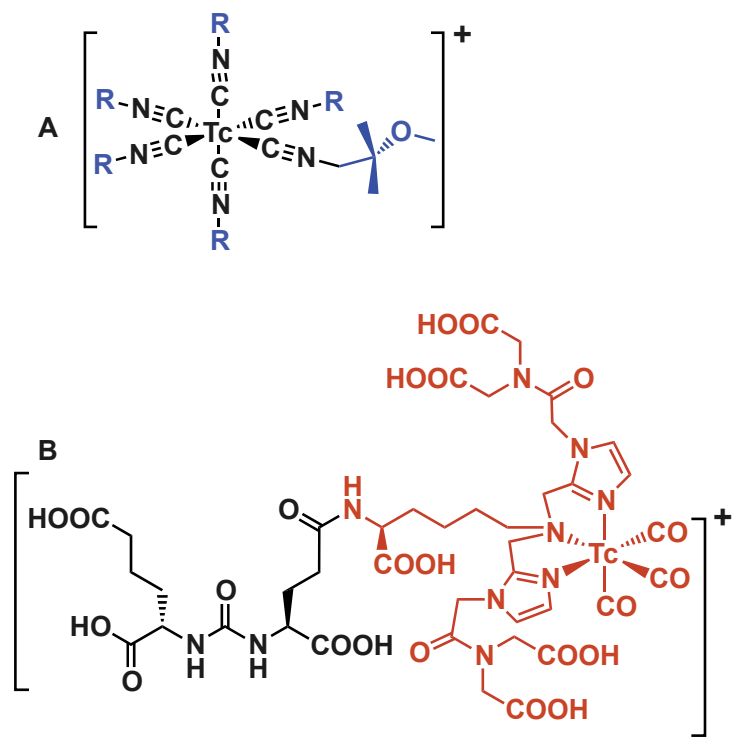

Fig. 2 Cardiolite ${ }^{\circledR}$, a de novo radiopharmaceutical in clinical use for many years ${ }^{[16]}(\mathrm{A})$ and MIP-1404 $(\mathrm{B})$ a targeting radiopharmaceutical based on the fac- $\left[{ }^{99 \mathrm{~m}} \mathrm{Tc}(\mathrm{CO})_{3}\right]^{+}$core. The black part in $\mathrm{B}$ is the receptor binding portion, the red part represents the spacer and the chelator. ${ }^{[18 a, c]}$ 
Apart from these application-directed aspects, we emphasize the educational aspect of technetium chemistry. Technetium is probably the only radioelement lighter than bismuth, with which chemistry with pure radioisotopes can be done on a macroscopic level. Only some elements of the actinide series offer the same opportunities. All radioisotopes of e.g. promethium are too short-lived or not available in larger quantities for performing common synthetic and analytical chemistry. Thus, technetium enables training in most radioanalytical techniques, in the handling of radioactive materials while the same time utilizing common chemical methods such as NMR spectroscopy or X-ray structure analysis. According to the Swiss Radiation Protection Regulations (StSV 814.501), the regulatory limit for ${ }^{99} \mathrm{Tc}$ is 2 $\mathrm{MBq}$, which corresponds to about $3 \mathrm{mg}$ of ${ }^{99} \mathrm{Tc}$. Of course, all ${ }^{99} \mathrm{Tc}$ experiments must be performed in respectively equipped laboratories with a Type $\mathrm{C}$ lab being sufficient for working with this radioisotope.

\section{Technetium and Rhenium Chemistry}

\subsection{Labelling with Building Blocks}

The building block methodology consists of a ${ }^{99 \mathrm{~m}} \mathrm{Tc}$ or, as a model, a Re or ${ }^{99} \mathrm{Tc}$ complex, which combines with appropriately designed ligands in their free form or are attached to a targeting molecule. The advantage of the building block model is that it allows for screening with many biomolecules without changing the nature of the tagged ${ }^{99 \mathrm{~m}} \mathrm{Tc}$ part. One example is the $\left[{ }^{99 / 99 m} \mathrm{Tc} \equiv \mathrm{N}\right]^{2+}$ building block (Scheme 1A). It is prepared in situ and coordinated in a second step to a variable PNP ligand and a dithiocarbamate carrying the biologically active unit. ${ }^{[19]}$ Many years ago, the complex $\left[{ }^{99 / 99 m} \mathrm{Tc}\left(\mathrm{OH}_{2}\right)_{3}(\mathrm{CO})_{3}\right]^{+}$was introduced which represents yet another building block. ${ }^{[20]}$ In this complex, the three water ligands are easily exchanged for essentially any ligand. ${ }^{[21]}$ The resulting complexes are highly robust and do not decompose or exchange any of the ligands. Those that have been subjected to biological studies are generally excreted unchanged. The versatility of this building block is mirrored by the numerous studies that have been performed over the years. They all have in common that they applied the same building block but altered ligands according to the respective purpose and biomolecule (Scheme 1B-F). ${ }^{[22]}$ The aforementioned MIP-1404 complex is a good example of how alterations in the ligand design finally led to a useful product. ${ }^{[18 c, d]}$ For full characterization, the corresponding ${ }^{99} \mathrm{Tc}$ or the Re homologues have been prepared in all cases.

As a representative example, the labelling of an amino acid with the $\left[{ }^{99 / 99 m} \mathrm{Tc}\left(\mathrm{OH}_{2}\right)_{3}(\mathrm{CO})_{3}\right]^{+}$building block shall be shown. To combine small molecules with a metal complex of any kind under retention of bioactivity or recognition by transporters presents true challenges. The metal complex may be larger than the carrier itself and the construct might rather end up as a complex with a complicated ligand than in a labelled biomolecule. For instance, there has been an intense research going on towards ${ }^{99 \mathrm{~m}}$ Tc-labelled glucose. The corresponding radio-fluorinated glucose $\left[{ }^{18} \mathrm{~F}\right][\mathrm{FDG}]$ is one of the workhorses of PET. For various reasons, it would be desirable to have a ${ }^{99 \mathrm{~m}} \mathrm{Tc}$-labelled glucose, but any attempt in this direction has been unsuccessful. ${ }^{[23]}$ Comparable in their function with glucose, amino acids are useful proliferation tracers. Amino acids are small and any conjugated complex may easily exceed the molecular weight of the carriers. We chose lysine as a starting point for targeting the L-type amino acid transporter LAT-1, known to be overexpressed on many cancer cell lines. ${ }^{[24]}$ Conjugating the small, but highly potent chelator 2,3-diaminopropionic acid (dap) via the $\alpha$-carbon to the terminus of the former lysine gave a labelled compound that was actively transported by LAT-1 (Scheme 2A). Its active uptake caused efflux since LAT-1 acts as an anti-port transporter. ${ }^{[25]}$ Shifting the conjugating position to the 2-amino group (for synthetic reasons) kept the overall composition and molecular weight intact but completely suppressed any biological recognition (Scheme 2B). This example corroborates how subtle changes in structures are decisive for the retention of bioactivities, in particular in small molecules. It also demonstrates nicely the challenges encountered when aiming at the development of targeting small molecule radiopharmaceuticals. Whereas the recognition by the transporter was excellent, in vivo studies did not show accumulation at tumor sites since the highly hydrophilic labelled amino acids were efficiently excreted before reaching the target. The core structure requires re-design, which yet again leads into basic, organic chemistry. Thus, designing the tracer chemically is a challenge, but to have it retained at the biological target even more so.
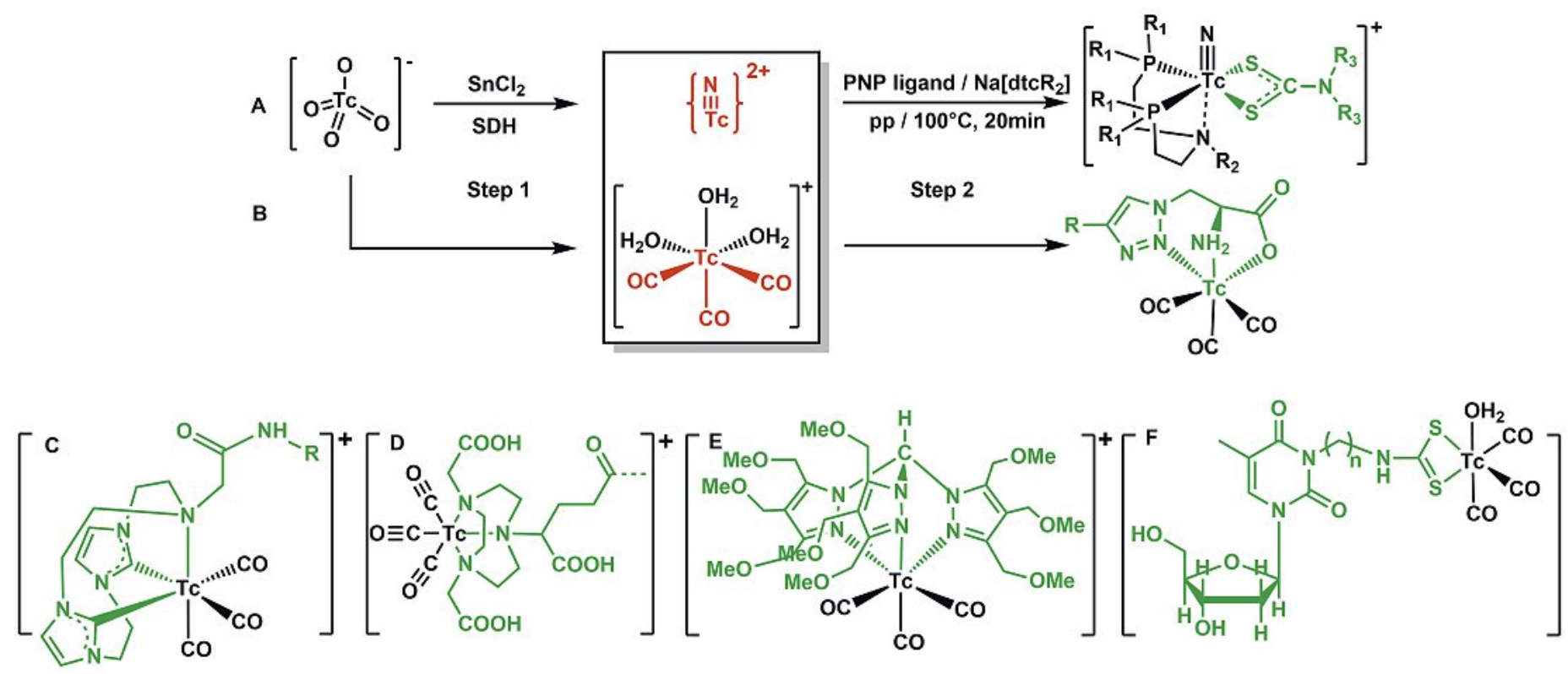

Scheme 1. The building block principle: The $\left[{ }^{99 / 99 m} \mathrm{TC} \equiv \mathrm{N}\right]^{2+}$ core allowing the coordination of multiple dithiocarbamates, carrying a targeting functionality $(\mathrm{A})^{[19 \mathrm{~b}]}$ and the $\left[{ }^{99 / 99 \mathrm{~m}} \mathrm{Tc}(\mathrm{CO})_{3}\right]^{+}$core $(\mathrm{B})$ with three available coordination sites for a variety of ligands, shown here a histidine mimic from the clickto-chelate approach. ${ }^{[22 a]}$ Examples: a bis-carbene ligand (C), ${ }^{[22 b]}$ coordination to NOTA, a derivative of 1,4,7-triazacyclononane (D), ${ }^{[22 c]}$ coordination of a tris-pyrazolyl-methane ligand yielding a myocardial imaging agent $(\mathrm{E})^{[22 \mathrm{e}]}$ and a dithiocarbamate carrying a targeting pyrimidine base $(\mathrm{F}){ }^{[22 \mathrm{C}]}$ The variable ligands for the respective core are shown in green. 


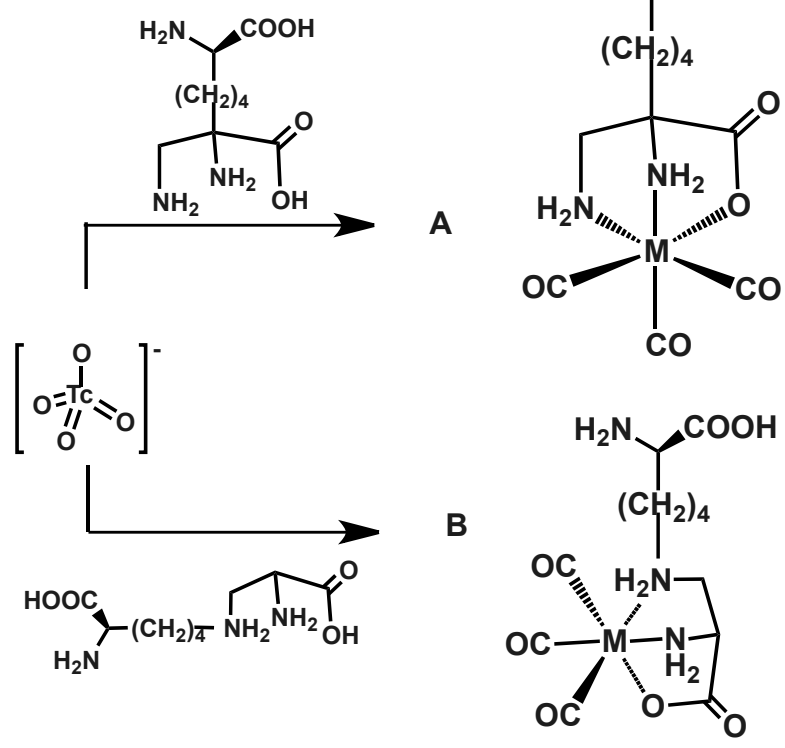

Scheme 2. Artificial amino acids; position of conjugation is changed, $\alpha-\mathrm{C}$ in $\mathrm{A}$ and 2- $\mathrm{NH}_{2}$ group in $\mathrm{B}$ respectively. Complex $\mathrm{A}$ is actively transported by LAT-1 whereas complex $B$ is not recognized by this transmembrane transporter, $(\mathrm{M}=\mathrm{Tc}, \mathrm{Re})$. $^{[25]}$

Extending the potential building blocks, the high-valent core fac $-\left[{ }^{99} \mathrm{Tc}^{\mathrm{VII}} \mathrm{O}_{3}\right]^{+}$was attractive since isolobal to the $\mathrm{fac}-\left[{ }^{99} \mathrm{Tc}(\mathrm{CO})_{3}\right]^{+}$ moiety. The chemical behavior of the two cores is evidently very different since $\mathrm{Tc}^{\mathrm{VII}}$ is strongly oxidizing but the coordination chemistry at the metal center might be comparable. Before attempting the synthesis with ${ }^{99 \mathrm{~m}} \mathrm{Tc}$, the corresponding chemistry was explored with ${ }^{99} \mathrm{Tc}$ to assess corresponding properties such as water stability on the macroscopic scale. A few model complexes of the general composition $\left[{ }^{99} \mathrm{Tc}\left(\mathrm{L}^{3}\right) \mathrm{O}_{3}\right]^{+}(\mathrm{L}=$ tridentate $\mathrm{N}$ or mixed N,O ligands) were synthesized and characterized but they all turned out to be instable in water, but instead hydrolyzed back to $\left[{ }^{99} \mathrm{TcO}_{4}\right]^{-}$. The only exception was the 1,4,7-triaza-cyclononane (tacn) ligand, which nicely stabilized the $f a c-\left[{ }^{99} \mathrm{Tc}^{\mathrm{VII}} \mathrm{O}_{3}\right]^{+}$ core towards hydrolysis. ${ }^{[26]}$ Following the logic-sequence of ${ }^{99} \mathrm{Tc}$ chemistry, i.e. transfer to ${ }^{99 \mathrm{~m}} \mathrm{Tc}$, the synthesis of the complex $\left[{ }^{99 \mathrm{~m}} \mathrm{Tc}(\operatorname{tacn}) \mathrm{O}_{3}\right]^{+}$was successfully achieved directly from water and $\left[{ }^{99 \mathrm{~m}} \mathrm{TcO}_{4}\right]^{-}$, as required for an eventual application. We emphasize here that while for ${ }^{99} \mathrm{Tc}$ any synthetic conditions can be applied, the application of the same conditions to ${ }^{99 \mathrm{~m}} \mathrm{Tc}$ demands generally a different mechanistic scheme. In fact, we found that $\left[{ }^{99 \mathrm{~m}} \mathrm{TcO}_{4}\right]^{-}$is activated in water with phosphonium salts, the reactivity of which allows for complex formation with tacn in water although $\left[{ }^{99} \mathrm{TcO}_{4}\right]^{-}$is the thermodynamically favored product. ${ }^{[27]}$ $\left[{ }^{99 \mathrm{~m}} \mathrm{Tc}(\operatorname{tacn}) \mathrm{O}_{3}\right]^{+}$represents a building block by itself since it reacts relatively rapid with alkenes by undergoing a cis-dihydroxylation under formation of the corresponding glycolato complex $\left[{ }^{99 / 99 \mathrm{~m}} \mathrm{Tc}^{\mathrm{v}} \mathrm{O}(\operatorname{tacn})(\mathrm{gly}-\mathrm{R})\right]^{+}$. Biomolecules can easily be derivatized with alkenes, thus, essentially any correspondingly functionalized vector can be labelled with ${ }^{99 \mathrm{~m} T c}$ along this pathway (Scheme 3). [28] As observed in many examples (vide infra), this reaction pathway to macroscopic $\left[{ }^{99} \mathrm{Tc}(\operatorname{tacn}) \mathrm{O}_{3}\right]^{+}$does not work in water starting from $\left[{ }^{99} \mathrm{TcO}_{4}\right]^{-}$or with $\left[\mathrm{ReO}_{4}\right]^{-}$but the complex is only accessible from organic solvents under different conditions.

It is somehow puzzling that the very same chemical reaction does not work with the very same isotope of an element, the only difference being the nuclear state. The reason for the difference lies rather in the fact that the reaction with one nuclear isomer is governed by kinetics $\left({ }^{99 \mathrm{~m}} \mathrm{Tc}\right)$, whereas the other is determined by thermodynamics $\left({ }^{99} \mathrm{Tc}\right)$, the deviation arising due to concentration differences. ${ }^{[29]}$ The achievement of a building block methodology

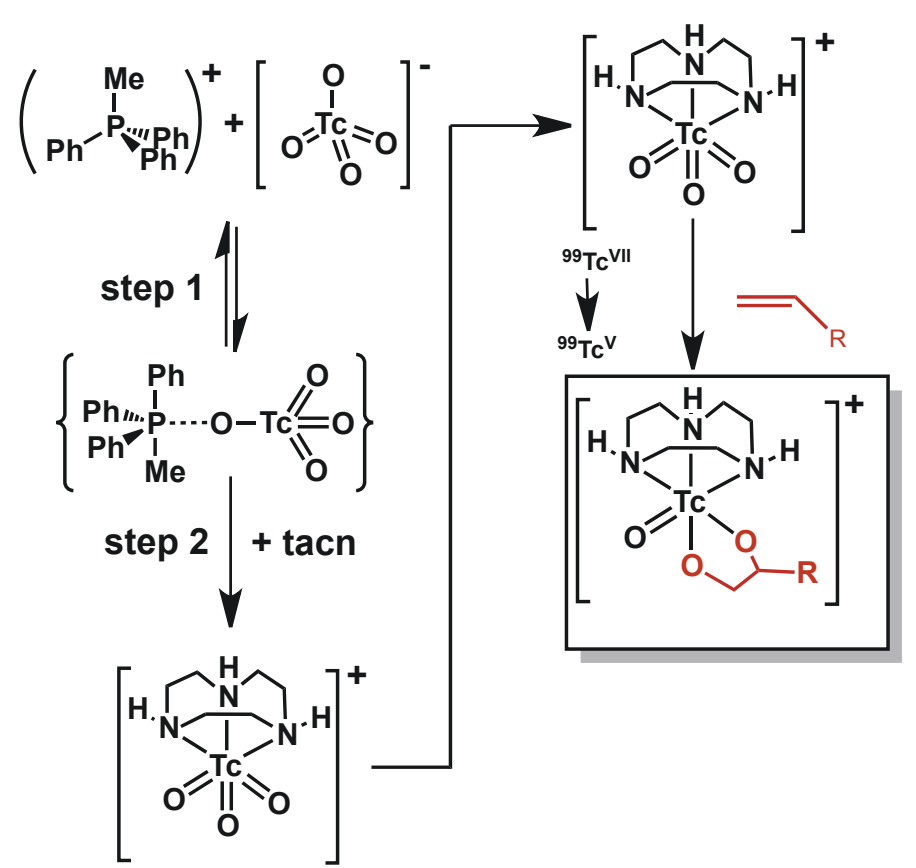

Scheme 3. High-valent ${ }^{99 / 99 m} \mathrm{Tc}$ chemistry: A water stable ${ }^{99} \mathrm{Tc}^{\mathrm{V}} \mathrm{ll}$ complex with 1,4,7-triazacyclononane (tacn) ligand, preparation with ${ }^{99 \mathrm{~m}} \mathrm{Tc}$ in water and further reaction with an alkene conjugated to any function 'R'. ${ }^{[27,28]}$

is challenging but it allows to go beyond single-step results. Only the building block methodology in technetium chemistry allows for a screening exploration of new radiopharmaceuticals of whatever kind, in a systematic and rapid way.

\subsection{Mimicking Pharmaceutical Lead Structures}

One of the strategies in bioorganometallic chemistry is the replacement of a substructure in a pharmaceutically active lead by an organometallic moiety. This concept was most successfully followed with ferrocene, which replaced a phenyl unit in, e.g. tamoxifen to yield ferrocifen but also in other organic compounds. ${ }^{[30]}$ A transfer of this approach to technetium, in particular to ${ }^{99 \mathrm{~m}} \mathrm{Tc}$, is not routine since the corresponding 'classical' organometallic complexes have to be synthesized in one step and from $\left[{ }^{99} \mathrm{mcO}_{4}\right]^{-}$ in water. Since pure 'technocene' does not exist, the ferrocene technology does not directly apply, but instead piano-stool complexes are an alternative. When aiming at the preparation of $\left[\left(\eta^{5}-\right.\right.$ $\left.\mathrm{C}_{5} \mathrm{H}_{5}\right)^{99 \mathrm{~m}} \mathrm{Tc}(\mathrm{CO})_{3}$ ], different hurdles have to be overcome, i.e. a six-electron reduction as well as the coordination of three COs and one typically water-insoluble HCp ligand, all of which has to happen at the same time in the same vial. However, carbonyl groups directly bound to the $\mathrm{Cp}$ ring reduce its acidity, which eliminates the solubility problem. In combination with boranocarbonate as a reducing agent $\left(\mathrm{Na}\left[\mathrm{H}_{3} \mathrm{BCO}_{2} \mathrm{H}\right]\right)$ and a $\mathrm{CO}$ source, the goal complex was prepared in one step and in quantitative yields. The carbonyl function may be conjugated to a targeting portion, e.g. to a serotonergic receptor binding part or other biofunctions, which enables target flexibility in this approach. Still, this does not yield a lead structure mimic but rather a second-generation targeting radiopharmaceutical. ${ }^{[31]}$ In extension, distinct organic synthetic approaches opened an access to multiply functionalized cyclopentadiene systems. These can now be derivatized with two different functionalities, whereby the central $\mathrm{Cp}$-ring may mimic a phenyl ring in a lead structure. The labelling of the free ligand under the original conditions leads again to integrated radiopharmaceuticals, resembling inactive, organic drugs. ${ }^{[32]}$ Cyclopentadiene chemistry is not routine. To introduce multiple functionalities in the HCp-ring is demanding organic chemistry since many of the resulting 'dienes' are reactive as such. The prep- 
aration of the corresponding rhenium or ${ }^{99} \mathrm{Tc}$ complexes relies on advanced organometallic and radiochemical methods. Together with the labelling procedures and the biological evaluations, these piano-stool complexes are another good example of the interdisciplinary nature of radiochemistry with elements directed towards imaging (Scheme 4).

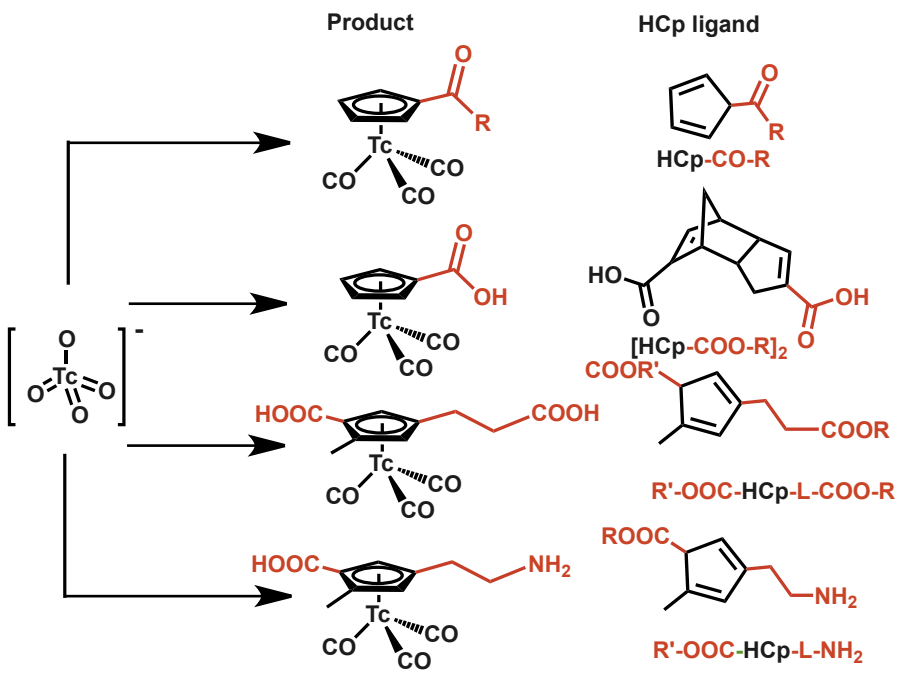

Scheme 4. Different approaches to mono- and multifunctional pianostool complexes of the general type $\left[(\mathrm{Cp})^{99 \mathrm{~m}} \mathrm{Tc}(\mathrm{CO})_{3}\right]$. All complexes are synthesized in a one-step procedure from $\left[{ }^{99 \mathrm{~m}} \mathrm{TcO}_{4}\right]$ in water. In second row, Diels-Alder dimer of cyclopentadiene carboxylic acid undergoes metal mediated retro Diels-Alder reaction, along with $\mathrm{Cp}$ coordination. In $3^{\text {rd }}$ and $4^{\text {th }}$ rows, ester group is hydrolyzed to acid under alkaline labelling condition. The red parts assign the coupling groups to targeting molecules. ${ }^{[32]}$

Cyclopentadienyls and their complexes, however, are not 'true' phenyls. Ideally, the phenyl in a lead structure would act directly as ligand, without the need to replace it in tedious and lengthy chemistry with a cyclopentadiene unit. But phenyls are not cyclopentadienyls and their complexes are typically much more sensitive to water and/or air. ${ }^{[33]}$ Their preparations are done under Fischer-Hafner conditions $\left(\mathrm{Al}^{0} / \mathrm{AlCl}_{3}\right)$, which are hardly compatible with highly functionalized pharmaceuticals. All these aspects speak against phenyl ligands playing an essential role in bioorganometallic chemistry or in molecular imaging. Still, especially the $\left[\mathrm{Ru}^{\mathrm{II}}(\text { arene })\right]^{2+}$ fragment is a central moiety in medicinal inorganic chemistry, albeit less for mimicking pharmaceuticals but more as being a cytotoxic compound as such. ${ }^{[34]}$ Arene complexes of rhenium and technetium were essentially unexplored in the past. Only one study reported cationic bis-arene complexes of the $\left[{ }^{99 \mathrm{~m}} \mathrm{Tc}\left(\eta^{6}-\right.\right.$ arene) $]_{2}^{+}$type, prepared along lengthy, multistep procedures following Fischer-Hafner conditions. ${ }^{[35]}$ We developed recently a new approach directly from $\left[\mathrm{ReO}_{4}\right]^{-}$or $\left[{ }^{99} \mathrm{TcO}_{4}\right]^{-}$to obtain various respective $\left[\mathrm{M}\left(\eta^{6} \text {-arene }\right)_{2}\right]^{+}$complexes in reasonable yields (Scheme 5). ${ }^{[36]}$ What came as a surprise was the extraordinary stability of $\left[{ }^{99} \mathrm{Tc}\left(\eta^{6} \text {-arene }\right)_{2}\right]^{+}$and their Re homologues. The complexes can be heated up to $160{ }^{\circ} \mathrm{C}$ in air and at almost any $\mathrm{pH}$ without decomposition. This contrasts with the bis-arene complexes of the neighboring elements, which either lose the arenes quite easily and/or are rapidly oxidized. For the preparation of ${ }^{99 \mathrm{~m}} \mathrm{Tc}$-based imaging agents, the stabilities are a very strong advantage. Once formed, they would not undergo any transformation/decomposition - however, the question remains how to form them in the first place. In ${ }^{99} \mathrm{Tc}$ or Re chemistry, the once coordinated arenes can be postsynthetically derivatized with a multitude of functionalities. With the scope of new imaging agents with ${ }^{99 \mathrm{~m}} \mathrm{Tc}$, this is not an attractive option as post-derivatization of arenes, of course, requires more steps for synthesis and purification of the desired biomolecules. The shorter half life of this radioisotope and its availability in water limits derivatization of benzene/arene once coordinated. [36b,37] Compared to the cyclopentadiene complexes, the solubility of arenes is a hurdle as well as the competition from other potentially coordinating ions and molecules in a labelling solution. That arenes would compete for water seemed unlikely and arene coordination typically demands 'naked' or coordinatively unsaturated metal fragments. Finally, an access to $\left[{ }^{99 \mathrm{~m}} \mathrm{Tc}\left(\eta^{6} \text {-arene }\right)_{2}\right]^{+}$ complexes was found directly from saline solution (Scheme 5). Since working in water, Fischer-Hafner conditions are obsolete. The reaction with reducing agents, the nature of which depends on the particular arene and on the presence of $\left[{ }^{99} \mathrm{TcO}_{4}\right]^{-}$, led to $\left[{ }^{99 \mathrm{~m}} \mathrm{Tc}\left(\eta^{6} \text {-arene }\right)_{2}\right]^{+}$in moderate to very good yields. The bis-arene complex is exclusively formed giving a high radiochemical purity. Arenes may be functionalized such as in estradiole and solubility issues became the limiting factor in extending the approach to an unlimited selection of arenes. ${ }^{[8 \mathrm{a}]}$ The development of bis-arene complexes from water would have been hardly feasible without radioisotopes as radioanalytical methods allowed for detecting the smallest 'impurities' in standard labelling methods for biomolecules, which later turned out to be the products, whose yield had to be optimized. Whereas it is now possible to prepare ${ }^{99 \mathrm{~m}} \mathrm{Tc}$ bis-arene complexes, the current challenge is to synthesize the rhenium homologues for the standard characterization of the ${ }^{99 \mathrm{~m}} \mathrm{Tc}$ bis-arene complexes. This situation differs from what is usually encountered for classical and cyclopentadienyl complexes of Re. The insights from preparing radiopharmaceuticals asks for the development of new organometallic procedures for Re or ${ }^{99} \mathrm{Tc}$ bisarene complexes, indispensable for the characterization of ${ }^{99 \mathrm{~m}} \mathrm{Tc}$ complexes.

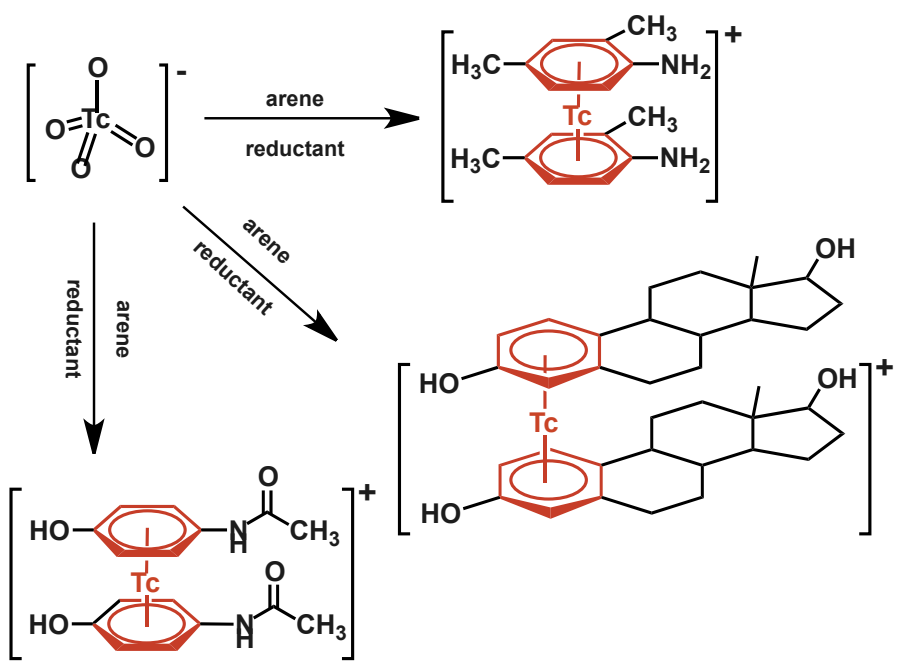

Scheme 5. Preparation of [ $\left.{ }^{99 \mathrm{~m}} \mathrm{Tc}(\text { arene })_{2}\right]^{+}$type complexes directly from $\left[{ }^{99 \mathrm{~m}} \mathrm{TcO}_{4}\right]^{-}$in water and in variable yields. Mixed arene complexes are available along this route as well. The challenge is the preparation of the Re or ${ }^{99} \mathrm{Tc}$ homologues and analogues respectively. Details are mentioned in the text. ${ }^{[8 a]}$

\section{Conclusions}

Synthetic chemistry with long-lived radionuclides such as ${ }^{99} \mathrm{Tc}$ is not just 'normal' chemistry demanding 'only' the consideration of additional risks of hazard. Although the related radioactivity makes research slower, options such as immediate quantification of product distributions, instant identification of minor amounts of (by)products, determination of molecular weights without $\mathrm{CHN}$ analysis and the prerequisite of a clean working approach are true assets in this field of radiochemistry. Chemistry can be done at high dilution at the tracer level such as with ${ }^{99 \mathrm{~m}} \mathrm{Tc}$. This enables 
chemical reactions and permits reactivities that would probably never be successful on the macroscopic level since kinetics often govern thermodynamics. None of the procedures mentioned above, and many more, elaborated for ${ }^{99 \mathrm{~m}} \mathrm{Tc}$, can be transferred straight away to $\mathrm{Re}$ or ${ }^{99} \mathrm{Tc}$. Imaging and radionuclide therapy with whichever radionuclide are probably applications for radionuclides with the strongest perspectives and with clear benefits for health care. Getting there requires unconventional approaches and indepth synthetic skills in inorganic and organometallic chemistry, taking the particular conditions of working with radionuclides into account. Technetium chemistry is not only of fundamental interest but it is even more, in its essence, application oriented. This brings along the need for interdisciplinary thinking and opens a view into the related fields of the life sciences, considerably enriching the perspectives of those working within this branch of radiochemistry.

\section{Acknowledgements}

The authors acknowledge support by the University of Zurich and the Swiss National Science Foundation. Numerous students made the progress of technetium chemistry possible, whose names are acknowledged in the respective references.

Received: August 11, 2020

[1] C. Perrier, E. Segre, Nature 1937, 140, 193

[2] a) G. E. Boyd, J. W. Cobble, C. M. Nelson, J. W. T. Smith, J. Am. Chem. Soc. 1952, 74, 556; b) G. E. Boyd, J. R. Sites, Q. V. Larson, C. R. Baldock, Phys. Rev. 1955, 99, 1030; c) C. M. Nelson, G. E. Boyd, W. T. Smith, J. Am. Chem. Soc. 1954, 76, 348; d) T. W. M. J. Smith, J. W. Cobble, G. E. Boyd, J. Am. Chem. Soc. 1953, 75, 5773 .

[3] a) P. Richards, W. D. Tucker, S. C. Srivastava, Int. J. Appl. Radiat. Is. 1982, 33, 793; b) F. F. J. Knapp, Eur. J. Nucl. Med. 1994, 21, 1151; c) L. G. Stang, W. D. Tucker, R. F. Doering, A. J. Weiss, M. W. Greene, H. O. Banks, Angew. Chem. Int. Ed. 1958, 70, 77.

[4] a) E. O. Fischer, M. W. Schmidt, Chem. Ber. 1969, 102, 1954; b) C. Palm, E. O. Fischer, F. Baumgartner, Naturwissenschaften 1962, 49, 279; c) U. Mazzi, Polyhedron 1989, 8, 1683; d) S. Jurisson, D. Berning, W. Jia, D. S. Ma, Chem. Rev. 1993, 93, 1137; e) S. S. Jurisson, J. D. Luxdon, Chem. Rev. 1999, 99, 2205; f) R. Alberto, in 'Compr. Coord. Chem. II', Vol. 5, Eds. J. A. Mc Cleverty, T. S. Meer, Elsevier Science, Amsterdam, 2003, p. 127; g) M. Nicolini, G. Bandoli, U. Mazzi, 'Technetium and Rhenium in Chemistry and Nuclear Medicine 3', Cortina International, Verona / Raven Press, New York, 1990; h) A. P. Sattelberger, J. C. Bryan, in 'Comprehensive Organometallic Chemistry', 1996, p. 151.

[5] a) F. Poineau, E. V. Johnstone, K. R. Czerwinski, A. P. Sattelberger, Acc. Chem. Res. 2014, 47, 624; b) E. V. Johnstone, F. Poineau, P. M. Forster, L. Z. Ma, T. Hartmann, A. Cornelius, D. Antonio, A. P. Sattelberger, K. R. Czerwinski, Inorg. Chem. 2012, 51, 8462; c) F. Poineau, E. V. Johnstone, A. P. Sattelberger, K. R. Czerwinski, J. Radioanal. Nucl. Chem. 2014, 299, 235.

[6] V. Drozdovitch, A. B. Brill, R. J. Callahan, J. A. Clanton, A. DePietro, S. J. Goldsmith, B. S. Greenspan, M. D. Gross, M. T. Hays, S. C. Moore, J. A. Ponto, W. W. Shreeve, D. R. Melo, M. S. Linet, S. L. Simon, Health Phys. 2015, 108, 520.

[7] a) A. E. Miroslavov, S. N. Britvin, H. Braband, R. Alberto, E. S. Stepanova, A. P. Shevyakova, G. V. Sidorenko, A. A. Lumpov, J. Organomet. Chem. 2019, 896, 83; b) F. Salsi, M. Neville, M. Drance, A. Hagenbach, C. L. Chen, J. S. Figueroa, U. Abram, Chem. Commun. 2020, 56, 7009; c) G. Claude, F. Salsi, A. Hagenbach, M. Gembicky, M. Neville, C. L. Chan, J. S. Figueroa, U. Abram, Organometallics 2020, 39, 2287; d) E. Reynolds, Z. M. Zhang, M. Avdeev, G. J. Thorogood, F. Poineau, K. R. Czerwinki, J. A. Kimpton, B. J. Kennedy, Inorg. Chem. 2017, 56, 9219; e) T. Yoshimura, T. Ikai, T. Takayama, T. Sekine, Y. Kino, A. Shinohara, Inorg. Chem. 2010, 49, 5876.

[8] a) Q. Nadeem, G. Meola, H. Braband, R. Bolliger, O. Blacque, D. HernandezValdes, R. Alberto, Angew. Chem. Int. Ed. 2020, 59, 1197; b) J. Baumeister, S. Jurisson, H. Hennkens, A. Mitchell, R. Cadena, J. Labelled Compd. Rad. 2019, 62, S297; c) C. Soderquist, J. Weaver, H. Cho, B. McNamara, S. Sinkov, J. McCloy, Inorg. Chem. 2019, 58, 14015.

[9] a) S. Chatterjee, G. B. Hall, M. H. Engelhard, Y. G. Du, N. M. Washton, W. W. Lukens, S. Lee, C. I. Pearce, T. G. Levitskaia, Inorg. Chem. 2018, 57, 6903; b) T. E. Phelps, N. Bhawawet, S. S. Jurisson, G. A. Baker, ACS Sus. Chem. Eng. 2018, 6, 13656.

[10] a) W. W. Lukens, N. Magnani, T. Tyliszczak, C. I. Pearce, D. K. Shuh, Environ. Sci. Technol. 2016, 50, 13160; b) M. Izquierdo, E. H. Bailey, N. M. J. Crout, H. K. Sanders, S. D. Young, G. G. Shaw, J. Hazard Mater. 2020, 388 ,
[11] Z. Soti, J. Magill, R. Dreher, EPJ Nuclear Sci. Technol. 2019, 5, 1

[12] a) J. Mattauch, Z. Phys. Chem. 1934, 91, 361; b) E. V. Johnstone, M. A. Yates, F. Poineau, A. P. Sattelberger, K. R. Czerwinski, J. Chem. Educ. 2017, 94,320 .

[13] A. Leonidova, G. Gasser, ACS Chem. Biol. 2014, 9, 2180

[14] a) S. Imstepf, V. Pierroz, R. Rubbiani, M. Felber, T. Fox, G. Gasser, R. Alberto, Angew. Chem. Int. Ed. 2016, 55, 2792; b) L. Quental, P. Raposinho, F. Mendes, I. Santos, C. Navarro-Ranninger, A. Alvarez-Valdes, H. Y. Huang, H. Chao, R. Rubbiani, G. Gasser, A. G. Quiroga, A. Paulo, Dalton Trans. 2017, 46, 14523; c) J. L. Hickey, E. J. Simpson, J. Q. Hou, L. G. Luyt, Chem. Eur. J. 2015, 21, 568; d) C. Sundararajan, T. R. Besanger, R. Labiris, K. J. Guenther, T. Strack, R. Garafalo, T. T. Kawabata, D. Finco-Kent, J. Zubieta, J. W. Babich, J. F. Valliant, J. Med. Chem. 2010, 53, 2612; e) A. Yazdani, N. Janzen, S. Czorny, J. F. Valliant, Inorg. Chem. 2017, 56, 2958.

[15] a) F. F. Knapp, A. L. Beets, S. Guhlke, P. O. Zamora, H. Bender, H. Palmedo, H. J. Biersack, Anticancer Res. 1997, 17, 1783; b) F. Roesch, F. F. Knapp, in 'Handbook of Nuclear Chemistry', Vol. 4, Eds. A. Vertes, S. Nagy, Z. Klencsar, F. Roesch, Kluwer Academic Press, Dordrecht, 2003, p. 81.

[16] a) M. J. Abrams, A. Davison, A. G. Jones, C. E. Costello, H. Pang, Inorg. Chem. 1983, 22, 2798; b) B. L. Holman, V. Sporn, A. G. Jones, S. T. B. Sia, N. Perezbalino, A. Davison, J. Listerjames, J. F. Kronauge, A. E. A. Mitta, L. L. Camin, S. Campbell, S. J. Williams, A. T. Carpenter, J. Nucl. Med. 1987, 28,13 .

[17] J. E. Cyr, D. A. Pearson, C. A. Nelson, B. A. Lyons, Y. Zheng, J. Bartis, J. F. He, M. V. Cantorias, R. C. Flowell, L. C. Francesconi, J. Med. Chem. 2007, 50,4295 .

[18] a) S. M. Hillier, K. P. Maresca, G. L. Lu, R. D. Merkin, J. C. Marquis, C. N. Zimmerman, W. C. Eckelman, J. L. Joyal, J. W. Babich, J. Nucl. Med. 2013 54, 1369; b) G. L. Lu, K. P. Maresca, S. M. Hillier, C. N. Zimmerman, W. C. Eckelman, J. L. Joyal, J. W. Babich, Bioorg. Med. Chem. Lett. 2013, 23 , 1557; c) C. Schmidkonz, C. Hollweg, M. Beck, J. Reinfelder, T. I. Goetz, J. C. Sanders, D. Schmidt, O. Prante, T. Bauerle, A. Cavallaro, M. Uder, B. Wullich, P. Goebell, T. Kuwert, P. Ritt, Prostate 2018, 78, 54; d) S. Vallabhajosula, A. Nikolopoulou, J. W. Babich, J. R. Osborne, S. T. Tagawa, I. Lipai, L. Solnes, K. P. Maresca, T. Armor, J. L. Joyal, R. Crummet, J. B. Stubbs, S. J. Goldsmith, J. Nucl. Med. 2014, 55, 1791

[19] a) K. Hatada, L. M. Riou, M. Ruiz, Y. Yamamichi, A. Duatti, R. L. Lima, A. R. Goode, D. D. Watson, G. A. Beller, D. K. Glover, J. Nucl. Med. 2004, 45 , 2095; b) N. Salvarese, B. Spolaore, S. Marangoni, A. Pasin, A. Galenda, S. Tamburini, G. Cicoria, F. Refosco, C. Bolzati, J. Inorg. Biochem. 2018, 183 , 18; c) A. Boschi, L. Uccelli, C. Bolzati, A. Duatti, N. Sabba, E. Moretti, G. Di Domenico, G. Zavattini, F. Refosco, M. Giganti, J. Nucl. Med. 2003, 44 , 806.

[20] R. Alberto, R. Schibli, A. Egli, A. P. Schubiger, U. Abram, T. A. Kaden, J. Am. Chem. Soc. 1998, 120, 7987.

[21] R. Alberto, R. Schibli, R. Waibel, U. Abram, A. P. Schubiger, Coord. Chem. Rev. 1999, 192, 901

[22] a) T. L. Mindt, H. Struthers, L. Brans, T. Anguelov, C. Schweinsberg, V. Maes, D. Tourwe, R. Schibli, J. Am. Chem. Soc. 2006, 128, 15096; b) C. Y. Chan, A. Noor, C. A. McLean, P. S. Donnelly, P. J. Barnard, Chem. Commun. 2017, 53, 2311; c) G. Makris, M. Kuchuk, F. Gallazzi, S. S. Jurisson, C. J. Smith, H. M. Hennkens, Nucl. Med. Biol. 2019, 71, 39; d) X. J. Duan, Q. Ruan, Q. Q. Gan, X. Q. Song, S. Fang, X. R. Zhang, J. B. Zhang, J. Organomet. Chem. 2018, 868, 154; e) L. Maria, C. Fernandes, R. Garcia, L. Gano, A. Paulo, I. C. Santos, I. Santos, Dalton Trans. 2009, 603

[23] a) D. M. Shin, D. Majumdar, X. H. Peng, Curr. Top. Med. Chem. 2010, 10 , 1211; b) M. Gottschaldt, U. S. Schubert, Chem. Eur. J. 2009, 15, 1548; c) M. Gottschaldt, C. Bohlender, D. Muller, I. Klette, R. P. Baum, S. Yano, U. S. Schubert, Dalton Trans. 2009, 5148; d) M. L. Bowen, C. Orvig, Chem. Commun. 2008, 5077.

[24] a) H. Nawashiro, N. Otani, N. Shinomiya, S. Fukui, H. Ooigawa, K. Shima, H. Matsuo, Y. Kanai, H. Endou, Int. J. Cancer 2006, 119, 484; b) T. Lahoutte, V. Caveliers, S. M. R. Camargo, R. Franca, T. Ramadan, E. Veljkovic, J. Mertens, A. Bossuyt, F. Verrey, J. Nucl. Med. 2004, 45, 1591.

[25] Y. Liu, J.-K. Pak, P. Schmutz, M. Bauwens, J. Mertens, H. Knight, R. Alberto, J. Am. Chem. Soc. 2006, 128, 15996.

[26] a) Y. Tooyama, H. Braband, B. Spingler, U. Abram, R. Alberto, Inorg. Chem. 2008, 47,257 ; b) H. Braband, Y. Tooyama, T. Fox, R. Alberto, Chem. Eur. J. $\mathbf{2 0 0 9}, 15,633$

[27] H. Braband, M. Benz, Y. Tooyama, R. Alberto, Chem. Commun. 2014, 50 , 4126.

[28] H. Braband, Y. Tooyama, T. Fox, R. Simms, J. Forbes, J. F. Valliant, R. Alberto, Chem. Eur. J. 2011, 17, 12967.

[29] R. Bolliger, A. Frei, H. Braband, G. Meola, B. Spingler, R. Alberto, Chem. Eur. J. 2019, 25, 7101

[30] a) G. Gasser, N. Metzler-Nolte, Curr. Opin. Chem. Biol. 2012, 16, 84; b) G. Jaouen, A. Vessieres, S. Top, Chem. Soc. Rev. 2015, 44, 8802; c) A. Nguyen, A. Vessieres, E. A. Hillard, S. Top, P. Pigeon, G. Jaouen, Chimia 2007, 61, 716; d) D. R. van Staveren, N. Metzler-Nolte, Chem. Rev. 2004, 104, 5931.

[31] a) J. Wald, R. Alberto, K. Ortner, L. Candreia, Angew. Chem. Int. Ed. 2001 40, 3062; b) J. Bernard, K. Ortner, B. Spingler, H. J. Pietzsch, R. Alberto, Inorg. Chem. 2003, 42, 1014. 
[32] a) A. Frei, E. Fischer, B. C. Childs, J. P. Holland, R. Alberto, Dalton Trans. 2019, 48, 14600; b) A. Frei, Chem. Eur. J. 2019, 25, 7074.

[33] G. Pampaloni, Coord. Chem. Rev. 2010, 254, 402.

[34] a) B. S. Murray, M. V. Babak, C. G. Hartinger, P. J. Dyson, Coord. Chem. Rev. 2016, 306, 86; b) R. H. Berndsen, A. Weiss, U. K. Abdul, T. J. Wong, P. Meraldi, A. W. Griffioen, P. J. Dyson, P. Nowak-Sliwinska, Sci. Rep. 2017, 7, 43005; c) R. Pettinari, A. Petrini, F. Marchetti, C. Pettinari, T. Riedel, B. Therrien, P. J. Dyson, Eur. J. Inorg. Chem. 2017, 1800; d) P. Y. Zhang, P. J. Sadler, J. Organomet. Chem. 2017, 839, 5; e) J. J. Soldevila-Barreda, P. J. Sadler, Curr. Opin. Chem. Biol. 2015, 25, 172.

[35] D. W. Wester, J. R. Coveney, D. L. Nosco, M. S. Robbins, R. T. Dean, J. Med. Chem. 1991, 34, 3284.

[36] a) M. Benz, H. Braband, P. Schmutz, J. Halter, R. Alberto, Chem. Sci. 2015, 6,165 ; b) G. Meola, H. Braband, P. Schmutz, M. Benz, B. Spingler, R. Alberto, Inorg. Chem. 2016, 55, 11131.
[37] a) G. Meola, H. Braband, S. Jordi, T. Fox, O. Blacque, B. Spingler, R. Alberto, Dalton Trans. 2017, 46, 14631; b) D. Hernandez-Valdes, G. Meola, H. Braband, B. Spingler, R. Alberto, Organometallics 2018, 37, 2910.

\section{License and Terms}

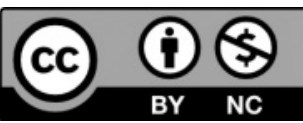

This is an Open Access article under the terms of the Creative Commons Attribution License CC BY_NC 4.0. The material may not be used for commercial purposes.

The license is subject to the CHIMIA terms and conditions: (http:// chimia.ch/component/sppagebuilder/?view=page\&id=12).

The definitive version of this article is the electronic one that can be found at https://doi.org/10.2533/chimia.2020.953 